\title{
A Sociological Study and Classification of Intellectuals in the Intellectual Field of Iran and the Role of this Field in the Process of Democratization of Culture from 1963 to the 1979 Revolution
}

\author{
${ }^{1}$ Amin Karami, ${ }^{2 *}$ Mehrdad Navabakhsh, ${ }^{3}$ Mansour vosooghi, \\ ${ }^{4}$ Seyed Mohammad Sadegh Mahdavi
}

\author{
Department of Sociology, Science and Research Branch, Islamic Azad University, Tehran, Iran \\ ${ }^{1}$ A.karami_1357@yahoo.com, ${ }^{2}$ Mehrdad_Navabakhsh@yahoo.com, ${ }^{2}$ Navabakhsh@srbiau.ac.ir
}

\begin{abstract}
In the present article in addition to Bourdieu's theory of social fields as the main theory, Antonio Gramsci's fourfold model regarding intellectuals and his theory of hegemony, as well as Karl Mannheim's democratization of culture theory, have been conceptually employed. To collect data first the characteristics of the fields of power, intellectuality and social classes are described. Then the sub-field of literature is studied as the witness field for democratic changes. Data collection has been carried out using documentary-library method, the sampling approach has been purposive or criterion sampling, and the sampling technique has been multiple purposive sampling including typical case and critical case sampling. This study shows that the intellectual field has played a great role in the process of democratization of culture in the chaotic period studied here, when intellectual discourses are opposed to each other as state-centered and nation-centered poles; the same polarization provides the basis for the democratic identification and distinction of the intellectual field.
\end{abstract}

Keywords: field, homology, intellectual competitions, democratization of culture, hegemony.

\section{Problem Statement}

The Constitutional Revolution and the 1979 Revolution are two important revolutions in the social history of Iran, in both of which different, and at times opposing, forms of thoughts can be detected. In most popular analyses these forms have been reduced to the contrast between tradition and modernism, resulting in repetitive, threadbare references. But what can be consistently detected in the periods before and after these two events is the presence of the intellectual field, in a way that various epistemic forms and the elite related to such cognitive forms, on the one hand, and the nature and content of the viewpoints and ideas of the intellectuals, on the other hand, throughout transition through these revolutions have caused the issue of the origin, formation, evolution and transformation of the intellectual currents and their presentable models to turn into an important concern for studies in the field of society and the academic space. A generation of intellectuals rose, with a liking for the democratization of culture and intending to fight dictatorship and oppressive governments; they tried to distinguish themselves and construct a field to form their special rules and logic and, in the words of Mannheim, pass through an aristocratic culture to a democratic culture. The analysis of intellectuality in Iran, because of historiographical, psychological and mostly ideological readings based on false-fabricated contrasts, has either resulted in the general denial of a large spectrum of the intellectual community in the name of treason or lack of identity, or through a personal and raw account has finally turned the intellectual space into a vulgar and trite space replete with abstract claims. What seems to be essential in these fields is the search for the process of distinction as the essence of modernity. In this process, the rule and regulations of the intellectual field and the positioning of the agents are based on economic, cultural, social and symbolic capitals that place the intellectuals in positionsbased on which intellectuals'actions are later oriented (Ritzer, 1999: 716). Such a situation causes Bourdieu, in his insistently putting the intellectuals under the sociological microscope, to consider intellectuals to have a paradoxical, two-dimensional being, and to be constructed by an instable solidarity, which is necessary for autonomy and commitment (Bourdieu, 2008,33 ). The structure of a field is the product of the history of that field, i.e., the constituting history of this field; in other words, the intellectual field in every period of its history is determined through power relations resulting from their inner conflicts, which are the outcomes of different 
strategies employed by actors (intellectuals) (Chauvire, Fontaine, 2006: 140-141). Similarly, Iranian intellectuals are placed within specific intellectual patterns according to their situation in the relevant field. These patterns, in their multi-dimensional relationship with power and the space of social classes, affect the movement of the Iranian society toward the democratization of politics, art, literature and culture. The culture of the Iranian society, with all its means and potentials, provides the context for the encounter between intellectual patterns and the conditions and construct of politics and power, and this theoretical attempt can be used as a study framework, once its patterns are determined. Therefore, a general question can be raised: with the participation of the intellectuals and the intellectual field in the cultural life of the Iranian society, do the morphology and the content of culture move in line with the process of democratization or non-democratization?

The Necessity and Importance of the Issue

i. The Iranian elite and intellectuals' dealing with political, cultural and social issues for more than 150 years as a result of modernity notwithstanding all the concerns from a modern point of view

ii. Lack of access to specific patterns and configurations of influential intellectual currents in the period leading up to the 1979 Revolution

iii. Theoretical confusion and ambiguity due to failure to understand the logic of intellectuals' action and strategy

iv. Superficial and hasty judgments, and unverified and non-historical advocacies in the form of binary analyses of sanctification/rebuking or confirmation/denial

v. An examination of the development and the logical process of the democratization of culture in non-Western countries

vi. The provision of methodological and epistemological diversities and referable frameworks for researchers

\section{The Theoretical and Conceptual System}

\section{Pierre Bourdieu's TheOry OF FieldS}

Influenced by physics and Douglas's "Theory of Lifestyle", in 1984 Bourdieu introduced the three concepts of habitus, position and distinction (Salam, 2006: 72). These concepts in his relational thinking make Swartz consider relational thinking necessary for field thinking (Swartz, 1997: 119). In Bourdieu's theoretical system, it is the essence of relationships that provides the basis for explaining the action of actors, and thus a two-fold description of the factor of action is presented: on the one hand, the social forces make actors conduct actions; on the other hand, actors carry out such actions based on inner motivations (Martin, 2003: 36).

\subsection{The Concept of Field}

According to Bourdieu, fields are defined through items, which are subject to conflict and controversy, such as cultural goods in the field of art or literature, power in the field of politics and status in the field of social classes; therefore, field is the constructed system of situations occupied by individuals (Jenkins, 2006: 135). Field is an independent and autonomous arena in which the identities of actors involved in the field are constructed in framework of the concept of habitus (Pinto, 1996: 106). Swartz, also, defines the concept of field on the basis of power because rival groups engage in struggles for the exclusiveness of a legitimate power, which by the definition of rules, leads to the acquisition of more capital and cementing the status of actors in the field (Calhoun, 1995: 6). In the framework of the theoretical elements of Bourdieu it can be said: social field > field of power > field of intellectuality.

\section{COMPLEMENTARY THeORIES}

\subsection{Karl Mannheim}

\subsubsection{Competition in Intellectual Life}

According to Mannheim, the general interpretation of the reality is the result of four kinds of social processes, which include four bases: 1. A process based on agreement or consensus, i.e. selfmotivated cooperation 2. A process based on exclusive situation of a special group 3. A process based on atomistic competition 4. A process based on a kind of concentration on a viewpoint revolving 
A Sociological Study and Classification of Intellectuals in the Intellectual Field of Iran and the Role of this Field in the Process of Democratization of Culture from 1963 to the 1979 Revolution

around competition about dominant poles (Mannheim, 2010: 310). The summary of Mannheim's conceptual help:

Table1.

\begin{tabular}{|l|l|}
\hline Theory & $\begin{array}{l}\text { Intellectual competition within four kinds of processes and as a cultural } \\
\text { phenomenon }\end{array}$ \\
\hline Conceptual help with data-finding & The concepts of exclusive, atomistic and focused intellectual competition \\
\hline $\begin{array}{l}\text { Categorical help with data finding and } \\
\text { analy sis }\end{array}$ & Polarization and hegemony \\
\hline Application as a comparative model & $\begin{array}{l}\text { A model based on presenting a categorization according to the attitude toward the } \\
\text { pure theory }\end{array}$ \\
\hline As an adaptable process & $\begin{array}{l}\text { Priority of the interpretation and explanation of intellectual movements in political } \\
\text { terms }\end{array}$ \\
\hline
\end{tabular}

\subsubsection{The Theory of Democratization of Culture}

Mannheim maintains that thereare two major cultures, namely the aristocratic culture and the democratic culture. He highlights de-distantiation, as opposed to distantiation, as a fundamental feature of the process of democratization (Mannheim, 1385: 66). One of the concepts of the democratization of culture is the idea of the relationship between culture and mentality and ideal, thus:

Aristocratic culture $\rightarrow$ aristocratic mentality $\rightarrow$ cultural ideal $\rightarrow$ aristocratic (elite) intellectual

Democratic culture $\rightarrow$ democratic mentality $\rightarrow$ cultural ideal $\rightarrow$ democratic (elite) intellectual

Table2.

\begin{tabular}{|l|l|}
\hline Theory & $\begin{array}{l}\text { Democratization of culture denotes the transformation of the form and content } \\
\text { of the mentality and ideals of aristocratic culture to democratic culture }\end{array}$ \\
\hline $\begin{array}{l}\text { Conceptual help with data } \\
\text { finding }\end{array}$ & de-distantiation, morphological attitude, disillusionment \\
\hline $\begin{array}{l}\text { Categorical help with } \\
\text { analysis }\end{array}$ & Democratic culture and the process of democratization of culture \\
\hline
\end{tabular}

\subsection{Antonio Gramsci}

\subsubsection{The Theory of Hegemony}

Althusserfinds Gramsci responsible for the historical humanistic interpretation of Marxism (Lowy, 1997: 153-156). The central concept of Gramsci, which reflects his inclination toward Hegel, is the concept of hegemony. This concept can be related to both the hegemonizer and the hegemonized; in the proletarian hegemony, it has a positive signification and in the hegemony of the ruling class, it has a negative signification (Ahmadi, 1996: 192). In his Prison Notebooks, Gramsci deals with power, especially the ruling class, and its role in producing and maintaining the kind of attitude to things, which does not challenge the status quo (Holub, 2011: 222.223).

\subsubsection{The Model of Intellectuals}

Gramsci distinguishes between two kinds of intellectuals: those who are intellectuals but do not carry out the duties of the intellectuals, and the intellectuals who fulfill the duty of enlightening in the society (Joll, 2009: 102). He also draws a distinction betweennon-public intellectuals: traditional intellectuals versus organic intellectuals. His four-fold model is as follows:

Model 1: traditional intellectual: artist, philosopher, andpoet

Model 2: the structure of emotions and the intellectual society

Model 3: organic intellectual, specializing in criticism

Model 4: public intellectual

Table3.

\begin{tabular}{|l|l|}
\hline Theory & The theory of hegemony and Gramsci's four-fold model of intellectuals \\
\hline $\begin{array}{l}\text { Conceptual help with } \\
\text { data-finding }\end{array}$ & The concepts of hegemony, the structure of emotion, group spirit \\
\hline $\begin{array}{l}\text { Categorical help with } \\
\text { analy sis }\end{array}$ & The categories of the traditional, new and public intellectual \\
\hline $\begin{array}{l}\text { The guiding process } \\
\text { in the research }\end{array}$ & $\begin{array}{l}\text { Differential pragmatic: 1. Assessment of roles and facilities of the intellectuals 2. Assessment of } \\
\text { ways of producing knowledge and their relationship with power 3. Examination of the conditions } \\
\text { of the production of critical knowledge }\end{array}$ \\
\hline
\end{tabular}




\section{The OPERATIONAL DEFINITION OF INTELLECTUAL}

The defining characteristics of intellectuals in the present article are: 1 . Non-conformity with their time and its demands, 2. Having the courage to look into the darkness of their time, 3. Identifying the archetype in the most modern and the latest issues, 4. Being critically minded, and 5. Being able to produce culture and ideology.

\section{The Operational Definition of Culture}

In the present article the evolutionary definition of culture is of importance. The characteristics of culture in the present article are as follows: 1. Culture as a product/construct, 2. Emphasis on symbol and symbolization, 3. Culture reproduced through education, 4. Culture as a composition of specific historical-geographical beliefs, knowledge and values, and 5. Transition from the material and empirical arena to the symbolic and linguistic arena.

\section{RESEARCH QUESTIONS}

\subsection{The Main Question}

A. With the participation of the intellectuals and the intellectual field in the period prior to the 1979 Revolution, would the morphology and cultural content be oriented toward democratization or nondemocratization?

\subsection{The Subsidiary Questions}

a. What are the characteristics of the intellectual field in the pre-1979 Revolution climate based onthe kind and amount of the capital of the intellectuals?

b. How is the strategy of Iranian intellectuals formed in response to the arenas of power and society?

c. What pattern of intellectual role has the opposition between the poles in the intellectual fieldconflicts created?

\section{RESEARCH METHODOLOGY}

\subsection{Attitude toward Research}

In this article, research has been considered as a periodic, interminable and examinable process. This kind of research is oriented toward critical explanation, trying to study the underlying conditions of the structure of the intellectual field and the objective situation of actors in this field, and uncover the basic hidden aspects of this phenomenon.

\subsection{Se lected Paradigm}

\subsubsection{The Critical Paradigm}

This paradigm is also referred to as dialectical materialism or class analysis, a paradigm that has combined the nomothetic and idiographic approaches and agrees with most of the criticisms the interpretive-constructivist approach has posed to positivism (Mohammadpour, 2010: 56).

\subsection{Bourdieu's Methodological Bas es}

\subsubsection{Bourdieu's Three Stages in the Study of Field}

First, the analysis of the field versus the field of power; second, drawing the map of the objective structure of relationships, occupied by the actors or institutions in the competition to gain capital or authority inside the field; and third, the analysis of the habitus concerning all situations in the social space by the researcher (Griller, 1996: 191). It can be said that actors or institutions are defined through their current potential position in the structure of the distribution of different kinds of power or capital; achieving these capitals leads to special interests and these interests are as important as objective relationships with other situations (hegemonizer, hegemonized, homological) (Waquant, 1989: 39).

\subsection{Data Collection Method: documentary-library method and biographical research}

5.6. Sampling Approach: purposive or criterion sampling

6.6. Sampling Technique: multiple purposive sampling, including typical case and critical case sampling 


\section{Data COLlection}

\subsection{The Characteristics of the Field or Structure of Social Classes}

in this period the structure of power was changed and as a result of land reforms two kinds of urban and rural class structures developed. In the early 1970s there were three distinct classes in the rural areas: 1. Absent farmers, including royal families, endowed lands and agricultural and industrial plans, 2. Independent farmers, including former rural land owners and families owning landed estates following land reforms, and 3. The lower rural class including agricultural workers, shepherds, construction workers in villages and industrial cities and small factories (Abrahamian, 2004: 392393). In cities, four classes can be identified:

i. The wealthy class: Pahlavifamily, aristocrats, aristocratic merchants, high-ranking officers and office workers, old merchants, and new merchants

ii. The rich or traditional middle class: businessmen, as the main part of this class, traders, and owners of stores and businesses and craftsmen

iii. The new middle class: teachers, school principals, engineers, governmental office workers and skilled workers

iv. Working class: employees in different sections of industry, who in the mid-1970s formed the larges class in contemporary Iran (ibid. 392-398).

\subsection{The Conditions of the Field of Power (Government and Politics)}

While the years between 1953 and 1963 could be regarded as the years of establishment ofthe power of the Shah (the king of Iran), the years 1963-1979 could be considered years of uneven development. The Shah does not try to develop a political system, open the political arena for different social forces, establish a bond between the regime and the new classes, preserve the existing bond and develop the social status of the monarchy (ibid, 398). The Shah considered the army his only supporter, and the army, bureaucracy and the support of the court constituted the main bases of the regime. In this period opposition political parties emerge; besides Tudeh Party of Iran, other active parties are as follows: 1. National Front: toward the end of 1954 and following the 1953 Iranian coup d'état, some important figures, who were secretly in contact with Mosaddegh, established the National Front of Iran; among the important figures were Sanjabi, Hasibi, as well as Bazargan and Mahmoud Taleghani (ibid. 419420). 2. Freedom Movement of Iran: in addition to Bazargan and Taleghani, Yadollah Sahabi, Ezzatollah Sahabi, Abbas Sheibani and SadeqTabataba'i have been involved in leading the party (ibid. 424).The OppositionClerics: following the 1963 uprising, three interdependent groups were formed inside the religious organizations. The first group included high-ranking non-political clerics such as Ayatollah Khoei, Ayatollah Khorasani, and Ayatollah Mar'ashi Najafi, who considered politics to be unclean. The second group was made up of moderate clerics such as Ayatollah Golpayegani, Ayatollah Shariatmadari and Ayatollah Milani. And the third group was composed of combatant clerics under the leadership of Ayatollah Khomeini in Iraq (ibid, 436-437). 4. Guerilla organizations in the years 1970-1979: the February 1970 Siahkal Incident, carried out by thirteen armed young guerillas, marked the beginning of guerilla activities; such activities were the result of social dissatisfaction and political frustration (ibid. 443). In the $20^{\text {th }}$ century two revolutions occurred in Iran. The Iranian Constitutional Revolution of 1905, resulting in a short-term victory for the intellectuals, was inspired by Western ideals, with the aim of establishing society based on nonreligious laws and Western models; but with the 1979 Revolution, clerics, who were inspired by the early Islam and condemned Western concepts, came to power and established religious rules (ibid. 489-490).

\section{The Characteristics of the Literary Sub-Field as the Witness}

In the years 1961-1979 the Iranian society experienced changes toward the development of capitalistic relations and the growth of the middle class. In this period, with the development of governmental capitalism, the expansion of the bureaucratic system, the rise in oil revenues and foreign investment, brokerage and stocks, the middle class grew considerably and started to lead a parasitic, monotonous life (Mirabedini, 2004: 405). The outcome of these changes made progressive writers develop a critical viewpoint and look for an indigenous solution. Following the period of the Iranian intellectuals' inclination toward the Western civilization in the years of the Constitutional movement 
and the cosmopolitan tendencies in the 1940s and 1950s, in the years 1961-1979 a kind of awakening occurs and the awareness of writers about the catastrophic conditions of society as the result of the political and propagative objectives of the government makes opposition an important theme in the literary works in this period. Opposition to the quasi-modernization in the Pahlavi Era results in the formation of a romantic tendency to "return to self" and thinkers such as Shariati and Al-e Ahmad look for Islamic traditions, and poets such as Akhavan Sales are in search of ancient Iran (ibid, 406407). In these circumstances and also due to lack of trust of some intellectuals in the influential power of literature, a group of intellectuals, without paying attention to the literary value of their literary production, start producing socio-centric literature with a sociological approach and thus hasty sociography once again grows considerably in the years following 1793 ( ibid. 419). The sociocultural changes in the 1960s make writers take a different view toward the issues of rural life, resulting in a new literary tendency known as rural-regional literature (ibid, 505). Urban literature is also influenced by the changes in the urban life. From 1961 onwards and in the years when social contradictions and the activities of guerrilla groups grew, the sociographers did not restrict themselves to describing the lives of the underprivileged, and reflected instances of opposition and resistance (ibid, 658). The avant-garde stories or the modernist literature of Iran in this period is characterized by a poetic opposition to the stabilized manifestations of bourgeois life.

\subsection{The Characteristics of the Intellectual Field}

NeginNabavicalls the years 1963-1970 the period of the emergence of the Third World-oriented intellectual. She believes thatthese intellectuals emerge with the uprising of June 5, 1963, against the reforms of the White Revolution (Nabavi, 2009: 133). In this period the regime increases its power through younger technocrats. However, unlike the early 1960s, when intellectuals were considered technical experts, in the late 1960s the word "intellectual" is used in a humiliating way, creating an image in which technocrats are represented as antithesis of intellectuals (ibid. 126-127). In the mid1960s, with the rise in intellectual activities, the intellectual magazine Negin is published, with Mahmoud Enayat as its manager and editor-in-chief. The necessity of rethinking the role of intellectuals becomes a pivotal point of intellectual discussion and the concepts of responsibility and duty, which are directly borrowed from the concept of commitment first brought up by Sartre, are vigorously debated (ibid. 130-131). Thus, unlike the 1950s the writer-intellectual becomes radical and is influenced the Third World-oriented discourse. Within the same discourse and conceptual space, the new image of cultural imperialism emerges and the contrast between the indigenous and the foreign intellectual heightens and new forms of this contrast are presented through terms such as 'the insider intellectual and imported intellectual', 'the combatant soldier and the wind-up doll', and 'the authentic intellectual and imitating intellectual' (ibid, 181-183). Nabavistates that in the years 19701978 some intellectuals became members of governmental institutions as honorary members. Intellectuals were employed by organizations, whose budget was provided by the government, the most important of which being the National Iranian Radio and Television (ibid, 207). In this period an opposition develops between the intellectuals employed by the governmental institutions and the extremist intellectuals not hired by any state institutions. Throughout these contrasts in the 1970s, the formation of a healthy society different from the technocratic society imposed by the West seems necessary to the intellectuals, and some of them, influenced by Marcuse and Fromm's criticisms of the age of technology, start to criticize the West; in the same vein, Eslami Nadooshan calls the technocrats technical politicians and obedient servants (ibid, 234-235). Out of this kind of thinking and in opposition to technocrats, a kind of spiritual revival is born, showing a tendency toward mystical interpretation; Mehdi Parham, who considers mysticism an alternative for the technocratic society, is an example of the thinkers treading this path (ibid, 237-241). It is of importance that while in the 1960s and 1970s the leftist, liberal and social democratic groups are announced illegal by the Pahlavi regime, religious centers grow considerably (Mirsepassi, 2004: 280). The clerics' attempt in the1960s and 1970s makes a large part of the community of clerics and their non-cleric fellows start a quiet struggle with the regime, supported by the educated and underprivileged people; this led to the development of a religious subculture and discourse connected with this struggle, turning into a serious challenge for the monarchy (Boroujerdi, 2008: 135). Along with the clerics, as one of the two important columns of the political culture of Iran, non-clerical intellectuals, especially in the 1970s, play an important role. Among these intellectuals are Ali Shariati, as an ideologue of the 1979 Revolution, and Seyyed Hossein Nasr, who, being influenced by Suhrawardi and Mulla Sadra, presents his intellectual approach in the framework of a four-fold plan (ibid, 155-188). Al-e Ahmad 
A Sociological Study and Classification of Intellectuals in the Intellectual Field of Iran and the Role of this Field in the Process of Democratization of Culture from 1963 to the 1979 Revolution

and Shariati, in an attempt to "return to self" and develop an indigenous and Islamic modernity, present Islam and the Shia faith as an ideology of modernization. In a similar way, in line with the anti-Western discourse, some intellectuals, now generally known as Fardidists (followers of Ahmad Fardid), rely on Heideggerian criticism and play a part in the intellectual arena of Iran in the 1960s. It can be said that the in 1960s and 1970s a lot of attention is paid to indigenization and localism, orientalism is vigorously challenged and questions are raised about self and the other in intellectual circles; people such as Shadman, Al-e Ahmad and Fardid, unlike Foroughi, Minovi and Taghizadeh, who paid no attention to Orientalism, engage in debate about Orientalism and Occidentalism (Boroujerdi, 2008: 198-199).

In hisPolitical Islam, Iran and the Enlightenment,Mirsepassi refers to the hopeless account of modernism in Iran with Heidegger as the most influential figure of this hopeless account (Mirsepassi, 2008: 47). According to him, Ahmad Fardid played the most important part in paving the way for a kind of political Heideggerian discourse in Iran. As a leading authority on German philosophy, especially Heidegger (ibid, 53), Fardid tried to reconstruct the East-West binary using philosophical concepts borrowed from Heidegger, and helped create an intellectual model, which engaged the interest of prominent intellectuals such as Al-e Ahmad, Shayegan, Ehsan Naraghi and Reza Davari (ibid, 53-55).

\section{The Democratic Discourse of this Period}

In the years 1963-1969 the discourse of religious democracy develops. In the late 1960s and early 1970s calls for democracy start to be heard and struggles with despotism and imperialism erupt all over the world. A wave of struggles starts in 1974, with the overthrow of dictatorship in Portugal, and sweeps Europe and is felt in Latin America; military governments are replaced by non-military, democratic governments (Shahramnia, 2006: 281). These universal movements, as well as the domestic conditions, the illegitimacy of the political system and anti-government discourses in Iran result in a disorganized narration in the democratic discourse. The democratic discourse in this period is a combination of the democratic discourses from the previous decades and the discourses of religious democracy and democratic democracy.

\section{DATA EXPLANATION AND ANALYSiS}

This section is intended to give answers to the four question raised above.

\subsection{Answer to the Main Question}

According to the data from the three fields, the period studied here, despite the inconsistency between its early years and the middle and final years, possesses the necessary elements and the context for the development of the intellectual field. In this period the intellectuals move ahead with the revolutionary changes and try to use the revolution to materialize their ideas, something that had not occurred in Constitutional Revolution. The field of the social classes in the urban and rural areas in this period, in line with considerable class changes, develops to a great extent toward the segregation of and distinction among different classes of the modern Iranian society and forms the setting for the development of modern class characteristics. This setting is formed especially from 1963 onwards within two class structures in urban and rural areas, structures that, influenced by the land reforms and changes resulting from it, incorporate the elements of class struggle. As a result, in the early 1970s a new class emerges among the rural classes, referred to as the middle-class farmers, and considered necessary for the formation of rural protest movements. An important point here is that while social classes in the rural areas are more influenced by the governmental-royal reform in the early 1960s than by the 60-year project of the development of state capitalism and the blessings of such a development, urban classes are affected by the implementation of the 60-year developmental plans and the royal reforms at the same time, the result of which is the formation of the wage-earning working class, as the largest class in contemporary Iran and the main force behind urban protests. In this period, the implementation of state formation/capitalism development by the dominant classes results in the fulfillment of the economic demands of the upper strata of the middle class, but it does not satisfy the cultural demands of the lower strata of the middle class and the social demands of the lower classes, the result of which is a lack of balance in the context of economic and cultural and social capitals, the dominance of economic capital, and the development of a protective shield for the governmental power through bureaucratic governmental system and modern army, which were 
supposed to stabilize the status quo and help secure the position of the grand apparatus through paving the way for a single-party state. The grand apparatus tries to find supporters among the technocrats who believe in the disciplined administrative system, powerful state party and technological and technical development through other apparatuses such as imported technology, rigorous bureaucracy, oil revenues and governmental army instead of national army. The development of Rastakhiz Party was based on the ideas of Samuel Huntington and in line with the capitalistic experience of the Iranian society. The development of this party improved the control and dominance of the state on all classes of people. The stabilization of the state and the institutionalization of the strengthening constructs of power widened the gap between the state and the nation. This gap, because of the emergence of the gap between governmental plans and promises and the demands of people, heightens the political and social tensions, which are revealed through the appearance of opposition parties emerging from the currents in the intellectual field. These parties adopt a more radical discourse, which is more influenced by the international, meta-field conditions than the domestic changes in intellectualpolitical logic of the existing currents. The global revolutionary situation of the 1960s finds its way the Iranian society and creates a climate in which the traditional middle class goes beyond its usual conservatism and joins the salary-earning middle class, forming a combined, non-conservative discourse. The unification of these two social strata is the result of the interchange and combination of economic and social capitals and the formation of a single front on the basis of the maximum capacity of these two capitals. Considering the class situation and the status of intellectuals in the intellectual field in answering the main question of the study, it can be claimed that the intellectual field plays a role in the process of the democratization of culture and the intensification and facilitation of the development of such a process. The reasons for this claim are as follows: 1. the formation of intellectual competition in the intellectual life of the intellectuals and also the presence of four kinds of processes of the interpretation of the reality, especially the processes of atomistic competition and the polarized focused competition based on Mannheim's model, 2. the formation of new methods of selecting the elite and recognizing the individual life of people in the framework of social movements and the abundance of reference groups for the democratization of the status quo, 3 . The emergence of the basic presupposition of democracy, i.e. the potential ontological equality of the social actors due to maximum involvement of the urban society in the revolution and the fundamental social, economic and cultural changes, 4. Removing the distance between the governed and the government and also between the elite and the mass and the formation of class awareness based on the same dedistantiation, 5.Disillusionmentregarding concepts such as power, the Shah and hegemonic dominance based on tendency to ancient past and racial nationalism, 6 . The formation of the democratic ideal and mentality, 7. The presence of intellectuals in the framework of Gramsci's organic model, intellectuals who do not resist democratic changes; and the formation of the public intellectual model, which is formulated in the periods of social crisis and in line with constructive changes among the mass, 8 . The development of class distinction and thus the development of roles for distinct rural andurban social classes on the basis of the type and amount of the four capitals introduced by Bourdieu, 9. The introduction of semi-agreed interpretation regarding democracy, and 10. The polarization of the intellectual field based on the type of relationship with state/politics.

\subsection{Answer to the First Subsidiary Question}

Two general, parallel, opposite currents can be detected; these currents use their accumulated power in two opposite ways: to protect the status quo or to put an end to the status quo. The current that protects the status quo belongs to the fields of power and capital, organized in the form of similar interdependent plans of state formation and capitalism. This current owes its existence to the activities of a part of the intellectual field and dominant social classes by relying on state economic capital. The second current, which seeks to put an end to the status quo, belongs to the political space and relies on people and is people-oriented. This current is developed within the project of the politicization of people and depends on the activities of another part of the intellectual field and the hegemonized social classes; it is based on social and cultural capitals and the real needs of people and their demand for liberation. There have been currents between these two major currents with different claims, which have finally joined one of these two poles in the intellectual field and paved the way for a more fundamental contrast, accompanied by conflicts such as tradition/modernity, West/East, revelation/science, spirituality/materiality, and progress/disaster. The intellectual field enters a new phase based on an inner field transformation with the uprising of June 5, 1963 and the reforms by the Shah. In this new phase, the intellectual supporters of the government are a generation of young 
A Sociological Study and Classification of Intellectuals in the Intellectual Field of Iran and the Role of this Field in the Process of Democratization of Culture from 1963 to the 1979 Revolution

technocrats, seeking to protect the status quo as an antithesis of the idea of intellectuality and as experts working for the government. Unlike these technocrats, who are estranged from the history and culture of Iran, the actors in the intellectual field start to rethink their performance and intellectual responsibility; as a result, more pragmatism can be seen in this field, and the discourses of young generation become more radical.

\subsection{Answer to the Second Subsidiary Question}

To answer this question the sub-field of literature,as the most important domain to examine the strategies of the intellectuals, is of great help. The domain of literature, as a charged domain with attraction-repulsion functions, possesses a somehow neutral and some major active and influential currents. The neutral literary current emerges around 1953, later known as"immigration literature", and continues until 1978. This kind of literature has the least, or even no, influence on the social, cultural or even literary field of the country and is practically disengaged from the political, social and cultural atmosphere and appears merely as an external and marginal current to the context of the Iran society. In the years 1963-1970, with the popularity of urban life, an increase in leisure time and the diversity of free time activities, phenomena such as radio, television, music and theater grow in popularity and as a result the written-visual culture changes in to an oral-auditory culture; in was within such changes and transformations that the literature of this period should have played its role in society and culture. The literary field, with such characteristics, in the pole distant from the statepower field, which includes the social or committed intellectual/writer, notices the strategies of riot, uprising and development of the culture of resistance. The active, critical intellectual, by opposing the quasi-modernization plan by the Pahlavi government and finding an indigenous solution, contributes to bridging the gap between the elite and people and dispelling the illusion of the unlimited power of the government. The literary/intellectual field of this period is situated between two strategies: the reformist strategy based on the reformations by the Shah in the 1960s, which later changes into the second strategy, which is a revolutionary strategy, leading to the fundamental changes in the late 1970s. These two strategies affect the existing poles and currents in the intellectual field, and are influenced by the way the intellectual field changes. The reformists admire the national government, and reformism, as a realistic ideology evolving gradually, stands against radical changes in social relations. This opposition is wrong because it brings about no structural reform and only fulfills the criteria compatible with the capitalisticdealings of production and bourgeois ownership (Lefebvre, 2012, 422-423). On the other hand, the currents opposing reform, with their revolutionary strategy, try to benefit from the gaps and schisms in the system to gain power and overthrow the system.

\subsection{Answer to the Third Subsidiary Question}

The reaction of the isolated, passive and introverted intellectual field in the previous period, discloses itself in this period in the form of political action in the political domain, a domain which the government had intended to seize through governmental capitalism and developing a single-party state. The result of such a reaction in the intellectual field and its changing into a surplus element unattainable for the government is the formation of opposition parties. While these forces are aware of their opposition with the government as the grand apparatus, they take the oppositions between interpolar and the inner-polar back to the intellectual domain; these oppositions put radical atmosphere of the intellectual space in homology with the dominating atmosphere. This atmosphere, along with the idea of gaining access to the transformed areas due to land reforms and attention to villages as the paternal home, gave a romantic hue to the virgin nature and the simple environment, the idea of getting back to oneself and the indigenous authenticity, which in conformity and homology with the main intellectual field evolved not as intellectual disinvolvement but as an action and a desire for searching for special domestic identity. Thus, the discourses of the religious modernists, the Third World-oriented intellectuals, the idea of return to oneself and the discourse of Westoxification along with the remains of suppressed currents of leftist radicalism and secular liberals create an atmosphere based the atomistic competition in the 1060s and 1970s; these atoms or particles, directly or indirectly, contribute to the formation of a concentrated discourse and current based on the discourse of orientalism. This discourse is configured under the influence of anti-modernization and antimachinism intellectuals, the critics of the popular Orientalism, the radical Third World-oriented approach with an emphasis on cultural imperialism, the indigenization-oriented approach based on a romanticism which is oriented toward past, the admiration of Iranian-religious traditions, the 
Westoxification discourse developed by Shadman and processed by Fardid, the Fardidism circle by relying on the Heideggerian philosophical critique of Western modernity, the synthesis of a combined approach between political Islam and leftist radicalism, opposition to technocracy and finally some elements from the radicalism of the leftist discourse.

\section{Conclusion}

The intellectual field in this period can be divided into the indigenization-oriented state-centered and the indigenization-oriented nation-centered intellectuals. Each group can be constructed in the form of two approaches of identity-oriented and religion-oriented approaches (adapted from Mansour Hashemi). Theindigenization-oriented state-centered intellectuals who have religious tendencies include non-political clerics who have seen theirrivals since 1963 in the field of political Islam and among political clerics. But the indigenization-oriented state-centered intellectuals with tendencies toward identity have an identity, not necessarily religious, concern in their re-readings of and opposition to the West and include two groups. One group includes intellectuals employed in governmental organizations, whose ideas are not included in the field of anti-government criticism, seeking fundamental changes in the system; they can be regarded as reformists, trying to fix flawed structures through giving instruction to the government. This group, because of the theoretical and practical limitations of their situation and as detectors of flaws in the governmental system, will take measures in order to improve the project of developing state and strengthening the bases of this process. The other group in this categorization incorporates Heidegger-oriented intellectuals, who contribute to the creation of a distinct language in the intellectual field, a language that creates a distance between people and such concepts and approaches. These intellectuals try to depoliticize the literary-intellectual and academic fields and sacrifice politics, as the domain of people, for philosophy, as the field of the elite. In the group of the indigenization-oriented nation-centered intellectuals both religion-oriented and identity-oriented approaches can be detected. The indigenization-oriented nation-centered intellectuals with religious tendencies include political, combatant clerics, radical religious intellectuals and religious modernists. Because of the secular nature of the Pahlavi government, their religious concerns and their closeness to people, rather than state and capital, these people are included in the nation-centered pole. On the other hand, the group of the indigenization-oriented nation-centered intellectuals with identity concerns includes the Third World-oriented and leftist radical people, who along with guerilla groups and uncompromising liberals try to revive politics in order to attain democracy and freedom using both the potential of the modernity project and the domestic capacity.

Therefore, in this period of fifteen years three intellectual currents are evolved alternately and systematically. These currents can be divided into Third World-orientedness against technocracy, governmental intellectuals as opposed to non-governmental intellectuals, and orientalist discourse against Occidentalism. In the class structure field, compared to the other two important fields, people are present in the form of Gramsci's public intellectuals. Their revolutionary presence directs the main body of the movement toward the democratization of the situation, bridging the gap between the intellectuals and the mass, dispelling the illusion about power, and establishing homology among all fields involved in the movement.

\section{REFERENCES}

[1] Abrahamian, Ervand (2004) Iran between Two Revolutions, trans. Kazem Firouzmand et al (Tehran: Markaz).

[2] Ahmadi, Babak (1996) Haghighat va Zibayi (Tehran: Markaz).

[3] Bashiriyeh, Hossein (2007) Tarikh-e Andisheha-ye Siyasi-e Qarn-e Bistom (Tehran: Ney).

[4] Boroujerdi, Mehrzad (2008) Iranian Intellectuals and the West, trans. Jamshid Shirzadi (Tehran: Farzan).

[5] Bourdieu, Pierre (2008) Acts ofResistanceAgainst the New Myths of Time, trans. Alireza Palasid (Tehran: Akhtaran)

[6] Calhoun, Craig (edi) (1995), Bourdieu: Critical Perspectives, Polity Press.

[7] Chauvire\& Fontaine (2006) the Vocabulary of Bourdieu, trans. Morteza Kotobi (Tehran: Ney).

[8] Griller, Robin (1996), the Return of The Subject? The Methodology of Pierre Bourdieu, In Critical Sociology, vol. 22, N-1, P 3-28 
A Sociological Study and Classification of Intellectuals in the Intellectual Field of Iran and the Role of this Field in the Process of Democratization of Culture from 1963 to the 1979 Revolution

[9] Holub, Renate (2011) Antonio Gramsci: Beyond Marxism and Postmodernism, trans. Mohsen Hakimi (Tehran: Cheshmeh).

[10] Hashemi, Mohammad Mansour (2007) Hoviyatandishan va Miras-e Farhangi-e Ahmad Fardid (Tehran: Kavir).

[11] Jahanbegloo, Ramin (2005) Iran dar Jostojooye Moderniteh (Tehran: Markaz).

[12] Jenkins, Richard (2006) Pierre Bourdieu, trans. Layla Joafshani and Hassan Chavoshian (Tehran: Ney).

[13] Joll, James (2009) Gramsci, trans. Mohammadreza Zomorodi (Tehran: Sales).

[14] Lowy, Michael (1997) On Changing the World, trans. Hassan Mortazavi (Tehran: Roshangaran va Motaleat Zanan).

[15] Mannheim, Karl (2006) the Democratization of Culture, trans. Parviz Ejlali (Tehran: Ney).

[16] Mannheim, Karl (2010) Articles on the Sociology of Knowledge, trans. Fariborz Majidi (Tehran: Sales).

[17] Martin, John Levi (2003), 'What is Field Theory?’ AJS.V109,N-1(July 2003):P 1-49

[18] Mirabedini, Hassan (2004), Sad Sal dastannevisi dar Iran, vol. 1 \& 2 (Tehran: Cheshmeh).

[19] Mirsepassi, Ali (2008), Iranian Intellectuals: Social Hope and Philosophical Despair, trans. AbasMokhber (Tehran: Tose' eh).

[20] Mohammadpour, Ahmad (2010) Zed-e Ravesh, Manteq and Tarh dar Raveshenasi Keyfi (Tehran: Jame'eshenasan).

[21] Nabavi, Negin (2009), Intellectuals and the State in Iran, trans. Hassan Fesharaki (Tehran: Shirazeye Ketab).

[22] Pinto, Louis (1996), 'The Theory of Field and Sociology of Literature: Reflection on The work of Pierre Bourdieu', International Journal of Contemporary Sociology, Vol 32, No-2.

[23] Ritzer, George (2003) Contemporary Sociological Theory, trans. Mohsen Solasi (Tehran: Elmi).

[24] Salam, A.M (2006) 'A Life Style Theories Approach for Affordable Housing Research in Sandi Arabia', Emirates Journal ForEngineering Research, vol. 11(1): P 67-76.

[25] Shahramnia, Amirmasoud (2006) Jahanishodan va Demokrasi dar Iran (Tehran: Negahe Moaser).

[26] Waquant, Loic. J.D (1989), 'Toward Reflexive Sociology: A workshop With Pierre Bourdieu, in sociological Theory, Vol. 7: PP-63.

[27] Wartz, David (1997), Culture and Power the Sociology of Pierre Bourdieu, the University of Chicago Press.

\section{AUTHORS' BIOGRAPHY}

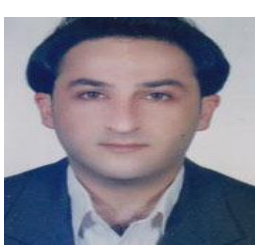

Amin Karami, finished his PhD in cultural sociology at Islamic Azad University, Science and Research Branch, Tehran, Iran. His fields of interest and study include critical sociology, and critical paradigm, and sociology of arts and literature. Both his $\mathrm{MA}$ and $\mathrm{PhD}$ theses were in the field of literature, intellectuality and intellectuals with a critical approach.

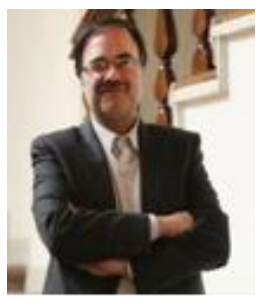

Mehrdad Navabakhsh, is an associate professor of sociology and a faculty member of Islamic Azad University, Science and Research Branch, Tehran, Iran. $\mathrm{He}$ is the president of Islamic Azad University, Central Tehran Branch as well. Dr Navabakhsh received his $\mathrm{PhD}$ from Islamic Azad University, Science and Research Branch, and did his postdoctoral study in legal-political sociology in France. His fields of study include urban sociology, management and urban development, city and citizenship rights, and social capital. 